\title{
SMART CITY IMPLEMENTATION IN BEKASI CITY
}

\author{
Brigitta Michelle*, Sushardjanti Felasari** \\ *) Department of Architecture, Universitas Atma Jaya Yogyakarta, Indonesia \\ **) Department of Architecture, Universitas Atma Jaya Yogyakarta, Indonesia \\ e-mail: brigittamich@gmail.com
}

\begin{abstract}
The advancement of information and communication technology has had a significant impact on the world as it increases people's needs and comfort. This can be seen in urban development with the formation of the concept of a smart city. This city integrates technological advances with people's lives to make effective decisions to improve the welfare of its people. This paper discussed the implementation of the brilliant city concept in Bekasi City, Indonesia. Along with its development, several intelligent city elements in Bekasi City are still far from expectations regarding the service quality and coverage. This study aims to see how brilliant city pillars are implemented in Bekasi City. Nonparticipant observation is used to conduct the research. The result shows that the range of innovative city application in Bekasi City is relatively narrow, and some service quality is still lacking. Only 10 out of 21 criteria have been fulfilled in the city. This research needs further study on the implementation of smart cities in other Indonesian cities to see the effectiveness of its application and other solutions that can be offered.
\end{abstract}

Keywords: intelligent city pillars, implementation, Bekasi City

\section{INTRODUCTION}

Innovations in technology drive changes in various aspects of life, including cities. The positive impact of technology development has been applied in the towns through the initiation of innovative city programs, a program that moves such an administrative area to use technological innovation to make decisions to improve the welfare of its people. In a smart city, this decision making is assisted by observations using technological innovations such as smartphones to be efficient in time, energy and costs.

Bekasi City is one of the cities that is part of the "100 Smart City" program in Indonesia, a joint program conducted by the Ministry of Communication and Information, Ministry of Home Affairs (Kementerian Dalam Negeri), Ministry of Public Works and Housing (Kementerian PUPR), Ministry of National 
Development Planning (Kementerian Perencanaan Pembangunan RI/ Nasional/Badan Perencanaan Pembangunan Nasional), and Presidential Staff Office (Kantor Staf Kepresidenan) (Devega 2017). The Smart City program in Bekasi City has been initiated since 2016, guided by the 2013-2018 Mid-Term Area Development Plan (Rencana Program Jangka Menengah Daerah) (Widodo and Permatasari 2020). In 2018, at the $3^{\text {rd }}$ Indonesia Smart Nation Award (ISNA), Bekasi City was granted the readiest city to implement innovative city initiatives. The city has the highest improvement rate out of 100 smart cities in Indonesia and has increased its ranking from the $23^{\text {rd }}$ to the $1^{\text {st }}$ ranking. Bekasi City implements six pillars of Smart City dimensions, i.e. competent government, innovative branding, smart economy, smart living, bright environment and intelligent society.

However, the success of the smart city implementation is influenced by the various factors that affect the quality and the scope of the pillars of the smart city, including Bekasi City. There are some examples of the implementation of a smart city in Bekasi that can be seen, i.e. mobile crowdsensing (Sanjaya, Supangkat, and Sembiring 2018), waste utility development (Saputra, Supangkat, and Iqbal 2017), how educating its citizen about smart city correlates with their attitude (Fanny 2017), its communication strategy (Widodo and Permatasari 2020), and information extraction for traffic congestion in social network (Alifi and Supangkat 2016). However, the study related to what extent or the quality of the smart city implementation in Bekasi City hasn't been done yet, nor the comparison among the performance of the city's pillars.

The study offers insights into the progress of the innovative city programs in Bekasi City by discussing each pillar. It is expected that the research could provide an overview of the performance of the creative city program in Bekasi City for future development.

\section{THEORY / RESEARCH METHODS}

A smart city is a government area that uses technology to provide benefits for its residents, such as health, inclusion, participation, environmental quality, and intelligence development (Dameri 2013). The smart city allows residents to connect with urban elements using technology (Northstream 2010). It takes data on the condition of their regional infrastructure and analyzes that data to make decisions and effective, preventive and safe (Hall et al. 2000). A smart city is a city that continues to innovate with the active participation of the community in various fields of life, including economy, social, government and the environment (Giffinger et al. 2007). It also connects physical, digital, social and business infrastructure to increase the collective intelligence of various elements of society (Harrison et al. 2010).

There are several pillars of a smart city, and it varies from one another. Giffinger includes a smart economy, smart people, smart governance, smart mobility, smart environment, and smart living (Giffinger et al. 2007). Meanwhile, Deloitte defines the smart city's pillars as smart governance, smart economy, smart mobility, smart environment, smart living, smart society, and smart people (Deloitte 
2015). Although the pillars differ in specifications and programs, all pillars are focused on using technology for elements of the city. In practice, they can be combined according to the city's needs. Bekasi City adapted smart city pillars from mainly Giffinger and Deloitte (see Table 1).

Table 1. Smart City Pillars Comparison

\begin{tabular}{|c|c|c|c|}
\hline & Giffer & Deloitte & Bekasi Smart City \\
\hline Smart economy & * & $*$ & $*$ \\
\hline Smart people & $*$ & $*$ & $*$ \\
\hline Smart governance & * & $*$ & $*$ \\
\hline Smart mobility & * & $*$ & \\
\hline Smart environment & $*$ & $*$ & $*$ \\
\hline Smart living & * & $*$ & $*$ \\
\hline Smart society & & $*$ & $*$ \\
\hline
\end{tabular}

Referring to table 1, smart economy is an economic network that develops new cooperation systems in production, distribution and consumption (Anttiroiko, Valkama, and Bailey 2014). Smart branding, part of smart economy, is a smart marketing strategy that increases investment and economic potential (Patabuga, Purnomo, and Kasiwi 2019). Smart government strives for community welfare by identifying and collecting data to fulfil community needs (Fioroni et al., 2015). Smart environment is an effort to use technology to increase knowledge about environmental conditions and energy use such as electricity, water and gas so that it can change people's bad habits, reduce waste, benefit the environment and increase the efficiency of resource use (Aletà, Alonso, and Ruiz 2017). Smart living is an effort to increase the efficiency of various public services, improve service quality and reduce infrastructure operating costs and public administration (Zanella et al., 2014). Finally, a smart society is an effort that uses the latest technology to improve society's quality of life (Valentyna et al., 2018).

The research employed nonparticipant observation. It focused primarily on statement while minimizing researchers' participation in interactions in the setting (Angrosino 2004). Comments are made by searching for secondary data regarding the smart city in Bekasi City from various journals and newspapers. The discussion is carried out inductively, containing evidence and examples of facts that conclude in the form of a general statement (Kurnia 2007). The processes are also be done by deepening the analysis through comparing findings with established concepts (Kurnia 2010).

Data analysis is run by finding programs made by the government, which then data will be categorized according to the smart city pillars. After that, the study was done further by comparing data with theories regarding smart city pillars published in books and journals.

Some criteria can also be used to analyze the implication of a smart city. city keys, a project funded by the European Union, has developed several measures to help smart city monitoring (Table 2 ). 
Table 2. CITY keys smart city criteria

\begin{tabular}{|c|c|c|}
\hline \multirow[t]{6}{*}{ People } & $\mathrm{H}$ & Health \\
\hline & $\mathrm{S}$ & Safety \\
\hline & AS & Access to (other) services \\
\hline & $\mathrm{E}$ & Education \\
\hline & DSC & Diversity and social cohesion \\
\hline & QB & Quality of housing and the built environment \\
\hline \multirow{5}{*}{ Planet } & EM & Energy \& mitigation \\
\hline & MWL & Materials, water and land \\
\hline & $\mathrm{CR}$ & Climate resilience \\
\hline & PW & Pollution \& waste \\
\hline & E & Ecosystem \\
\hline \multirow[t]{6}{*}{ Prosperity } & EM & Employment \\
\hline & EQ & Equity \\
\hline & GE & Green economy \\
\hline & EP & Economic performance \\
\hline & $\mathrm{I}$ & Innovation \\
\hline & $\mathrm{AC}$ & Attractiveness \& competitiveness \\
\hline \multirow[t]{4}{*}{ Governance } & $\mathrm{O}$ & Organization \\
\hline & $\mathrm{CC}$ & Co-creation \\
\hline & $\mathrm{CE}$ & Community engagement \\
\hline & MLG & Multi-level governance \\
\hline
\end{tabular}

\section{RESULTS AND DISCUSSION}

\section{Smart Government Pillar of Bekasi City}

In terms of smart government, the government of Bekasi City have issued several programs regarding the digitization of public services. It can be seen from public service facilities that made integrated into the Bekasi Trade Center Public Service Mall (MPP BTC).

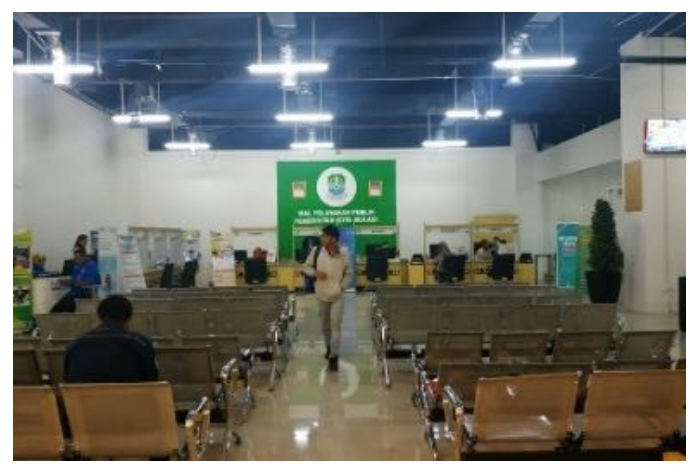

Figure 1. MPP BTC

Source: megapolitan.kompas.com 
MPP BTC serves citizens' needs such as extending driving licenses (SIM), making police records (SKCK), birth and death certificates, making building taxes (PBB) mutation, water (PDAM) payments, Hajj registration, and passport processing. MPP BTC serves an integrated electronic business license system or OSS (single online submission), registered through the OSS website or the helpdesk of the Investment and One-Stop Integrated Services Service. (Mantalean 2019). There are also other services provided, such as a SIMPELBANG that monitors the performance of the city government, SIKERJA for performance report of the civil servants in Bekasi City, and a mobile application e-OPEN for documentation.

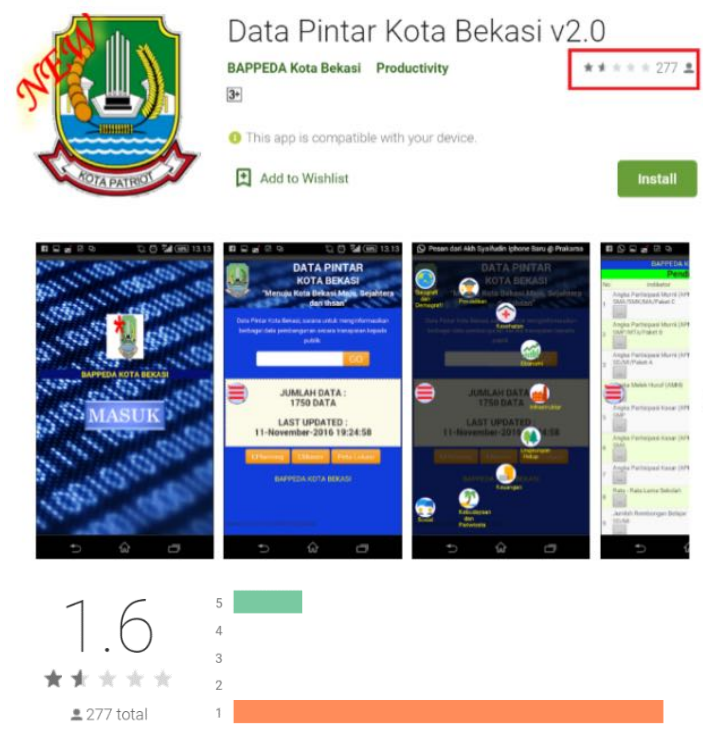

Figure 2. Bekasi City Smart Data Application v2.0 (screen capture) Source: play.google.com

In general, it can be said that the public services provided by the government of Bekasi City are pretty good. However, some services are still lacking, including Smart Data for Bekasi City v2.0. Figure 2 shows the Bekasi City Smart Data application v2.0 scored 1.6 out of 5 stars by the users (the community) as it cannot be opened.
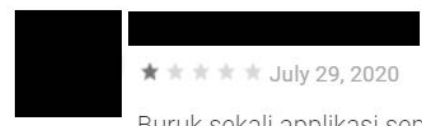

Buruk sekali applikasi seperti ini, setelah di download ga bisa dibuka dengan keterangan koneksi gagal dan disuruh coba lagi. Setelah diklik coba lagi ga respon. Bagusan website simpaduk kota bekasi yg sebelumnya dalam pengurusan dokumen untuk ektp, akte lahir, kk dll. Maaf Pak Walikota Bekasi Bang Pepen, anda gagal dalam melayani masyarakatnya yg dulu anda gembar gemborkan untuk melayani warga kota bekasi. Not respect anymore

Figure 3. Review of Bekasi City Smart Data Application v2.0 (screen capture) Source: play.google.com 
One review stated the application couldn't be opened because of connection failure (Figure 3). This should be improved by fixing the error so that it can be used accordingly in the future. The user interface should be easy to understand, and most importantly, it has to work smoothly.

Bekasi City has used websites and mobile applications to provide further services. Some programs in the smart government pillar have helped the citizens by providing easier registrations for legal needs and thus making the services run faster. Citizen data collecting has been done digitally using the mobile application Bekasi City Smart Data v2.0. Still, the service is useless because it cannot be opened and cannot be used. In general, the programs are aligned with the smart government pillar.

\section{Smart Branding Pillar of Bekasi City}

The only program for smart branding in Bekasi City has been done by using signage located at the main street in Bekasi city (Figure 4). The application of Smart Branding in Bekasi City was carried out at the pedestrian Jl. A. Yani. This arrangement refers to the concept of urban design, where the pedestrian construction is supported by other facilities such as parks, benches, and street lighting (Fajri 2017).

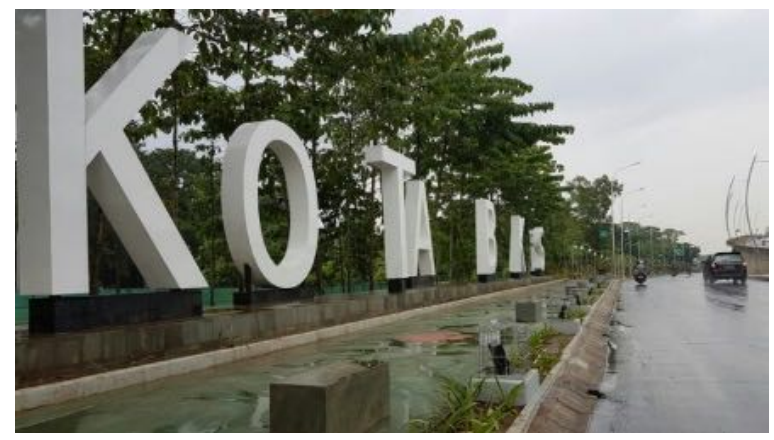

Figure 4. Pedestrian Ahmad Yani Street, Bekasi City Source: wartakota.tribunnews.com

Redesigning branding signage at the pedestrian walkways in Jl. A. Yani, the main road in Bekasi City increases the city's attractiveness. It elevates its image (Figrbut increase its economic sectors indirectly. Various programs are still needed to build a strong branding that incorporates economic sectors to create a smart branding.

\section{Smart Economy Pillar of Bekasi City}

The study has found one program intended for a smart economy in Bekasi City called KOMBAS (Bekasi Batik Community). Its products include clothes, bags, shoes, bags, t-shirts, and souvenirs (Firdaus 2018). Every Friday, there is a free 
workshop, which is conducted in its gallery, De' Bhagasasi (Bekasiekspres.com 2019).

KOMPAS also facilitates batik producers in Bekasi City to display and sell their products. The KOMPAS utilizes the latest technology to improve businesses. Using its website, the batik producers could sell the product so the effects can be distributed quickly to potential customers.

\section{Bright Living Pillar of Bekasi City}

There are several programs issued by the government of Bekasi City regarding the digitization of several services to support the citizens' living. Chasbullah Abdul Madjid Hospital in Bekasi City is one of the examples that enforces online registration and is ready to deliver drugs by the medicine delivery services called "Siap Antar Obat" (Pemerintah Kota Bekasi 2020). There are also other services called a "LAPOR" (Layanan Aspirasi dan Pengaduan Online Rakyat) application for reporting community problems (Figure 5) and "SILAT" (Sistem Layanan Perizinan Terpadu) for legal permit.

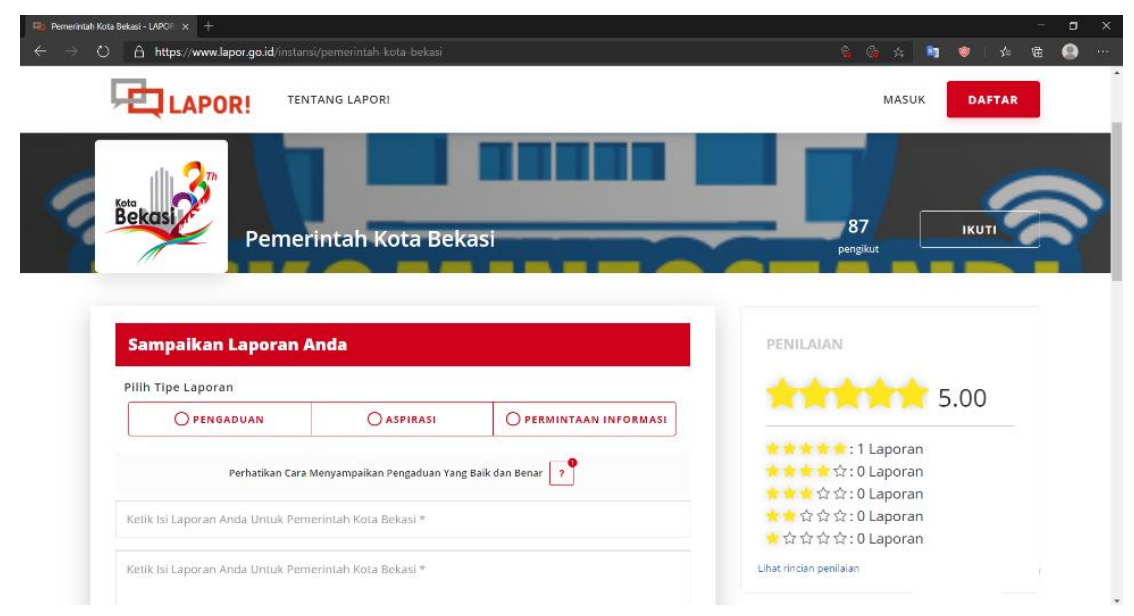

Figure 5. LAPOR (website screen capture)

Source: bekasikota.lapor.go.id

Medicine Delivery Services (Siap Antar Obat), LAPOR, and SILAT make services easier for citizens by providing online services; thus, reducing operating costs, although energy saving, in general, hasn't been applied to the programs. In general, the programs are accurate to the original intention, which is intelligent living.

\section{Smart Environment Pillar of Bekasi City}

There are two programs for the smart environment that has been implemented in Bekasi City. The circular letter from the Mayor of Bekasi SE Number 660.1/6315/ Dinas LH dated 27 September 2019 has prohibited using plastic bags in the Bekasi 
Mayor's Office Environment (Pemerintah Kota Bekasi 2020). Bekasi City Government and the social enterprise Waste4Change are working together for smart city-based waste management. One of the projects that have been realized is the procurement of a German-manufactured garbage ship with a capacity of 300 kilograms of waste, which is planned to be operated in the Bekasi River (Mantalean 2020).

There are two approaches to achieving a smart environment: saving energy and efficiently managing resources (Millard et al., 2014). The programs in Bekasi City are primarily concerned about trash accumulation and its management. Therefore, they fulfil the smart environment criteria at some point. Programs regarding energy saving can be introduced further in the future to apply the smart environment pillar fully.

\section{Smart Society Pillar in Bekasi City}

The government issues several programs regarding the digitization of societal needs. The SiTikTIk Jumantik (Juru Pemantau Jentik) application is one program that has been implemented to detect and report dengue-borne mosquitos. Other programs, i.e. Flood EWS (Early Warning System), IWMS (Integrated Waste Monitoring System) to monitor garbage cars installed with GPS, and RT RW LapKin (RT RW Laporan Kinerja) application to report neighbourhood performance (Rachmat 2018).

The programs issued by the government in this pillar facilitates the use of mobile applications to warn the community about diseases (SiTikTIk Jumantik). It can observe local neighbourhood performances (RT RW LapKin) where the applications encourage citizens to self-report. Therefore, it facilitates community independence. Other programs use technology to detect disaster and send early warning system (Flood EWS) and observe performances (IWMS) to increase the effectiveness of mitigation and improve public services. Therefore, the programs are aligned with the intelligent society pillar.

In addition to the analysis above, the implementation of smart city pillars in Bekasi city is also be marked by the criteria developed by CITYkeys criteria (Table 3 ). The requirements divided into four categories, i.e., people, planet, prosperity, and governance. Those categories then also divided into sub-categories linked to smart city development. To analyze the programs issued for smart city in Bekasi City, each pillar is divided according to the agenda, and the scoring is divided into CITYkeys criteria. The criteria surpassed by the projects are given marks.

Table 3. Smart city in Bekasi City analysis

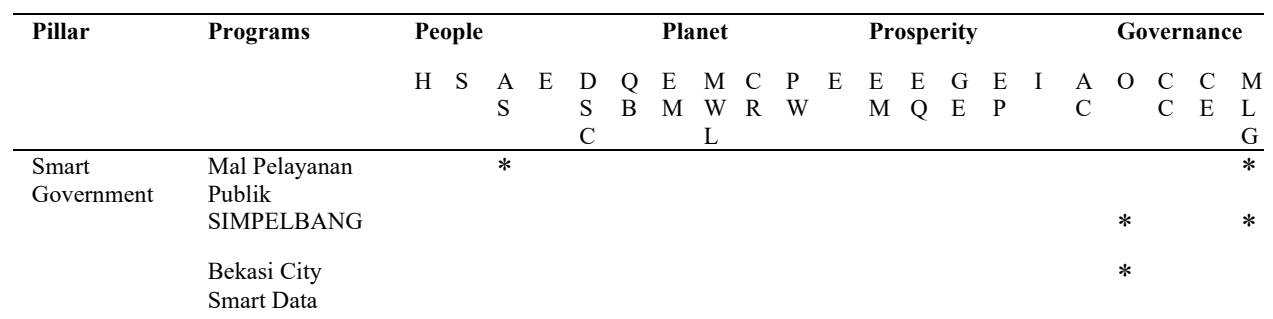


Table 3. Smart city in Bekasi City analysis (continued)

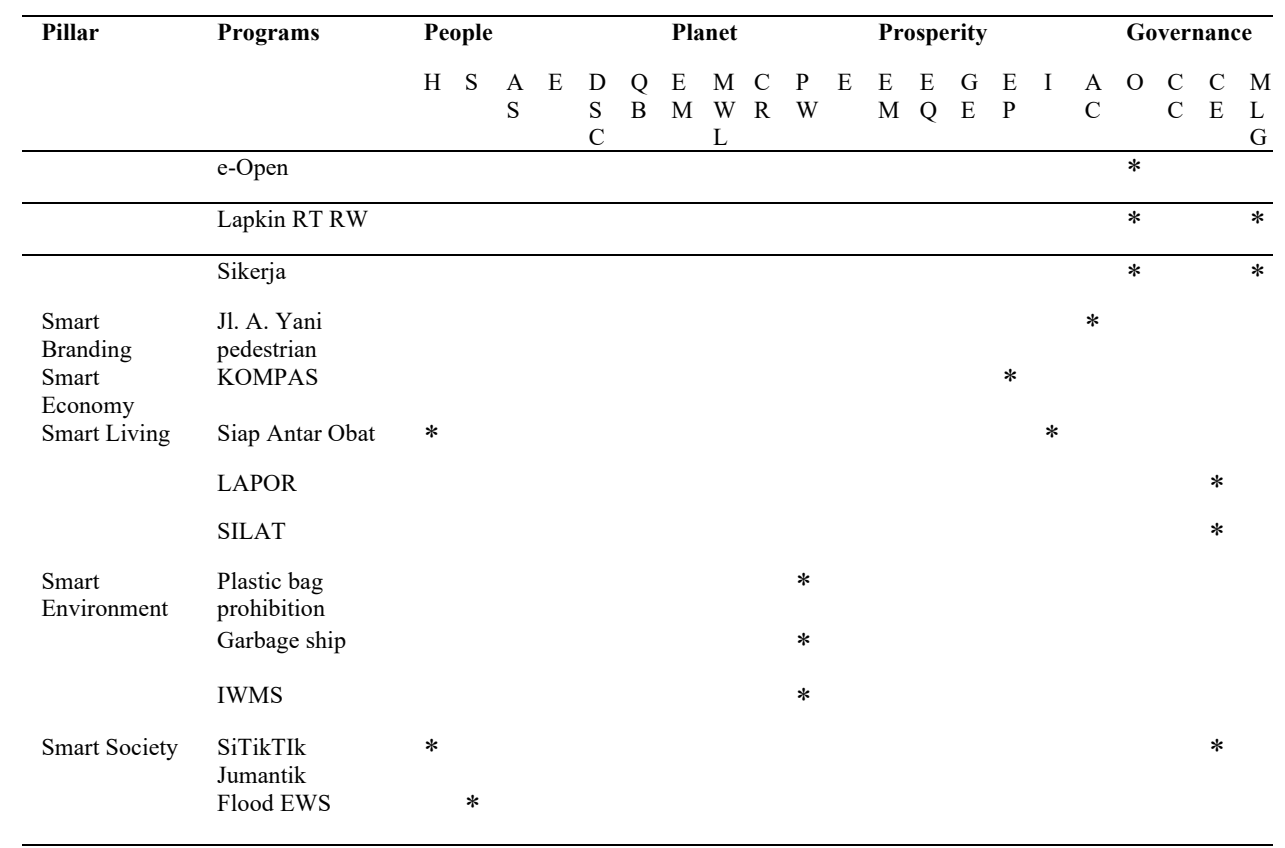

Explanations to each smart city pillars are as follows. Programs in the smart government pillar fulfil three sub-categories which are access to (other) services (AS) in the people category and organization (O) \& multi-level governance (MLG) in the governance category.

Smart government takes advantage of technological advances to improve the performance of government services (Shamsi et al., 2018). Smart government enhances community collaboration with the government to provide fast, affordable, scalable and sustainable government services (Howard 2013). Mal Pelayanan Publik, SIMPELBANG, Bekasi City Smart Data, e-Open, Lapkin RT RW, Sikerja are in line with the smart government, and they fulfil mostly organization $(\mathrm{O})$ and multi-level governance (MLG) sub-categories. Co-creation and community engagement are not included in the programs; thus, the programs still lack active participation from the citizens to develop the programs.

Program in smart branding is aimed to fulfil attractiveness \& competitiveness (AC) in the prosperity category. Developing smart branding aims to improve various economic sectors such as small and medium enterprises, tourism, creative economy, agriculture, fisheries, and different other economic sectors (Pasquinelli 2015). Jl. Ahmad Yani pedestrian doesn't directly fulfil the smart branding goal of increasing investment and economy. Although it increases the attractiveness in the city, it doesn't now cause economic competitiveness because it doesn't tackle the issue from a financial perspective.

Program in smart economy fulfils economic performance (EP) in prosperity category. A smart economy is an economy that uses the latest technology, innovation, resource efficiency, environmentally friendly production, high social 
welfare to achieve benefits for all parties (Galperina, Girenko, and Mazurenko 2016). KOMPAS facilitates Bekasi batik sellers in one place and uses the website to increase the community's economic performance. Although the smart economy doesn't tackle other criteria of CITYkeys' prosperity, such as equity and green economy, it still helps the Bekasi batik community secure its economic performance.

Programs in smart living fulfil health $(\mathrm{H})$ in the people category, innovation (I) in the prosperity category, and community engagement (CE) in the governance category. Smart living is a lifestyle that applies energy saving principles, guaranteed public services, and a good quality of life for humans (Liu et al. 2016). Siap Antar Obat, LAPOR, and SILAT are in line with smart living, and they increase the quality of life and public services. The programs are still primarily focused on public governmental service because only 1 out of 6 criteria of CITYkeys' people fulfilled.

Programs in smart environment fulfil pollution \& waste (PW) in planet category. There are two approaches to achieving a smart environment: saving energy and efficiently managing resources (Millard et al., 2014). Plastic bag prohibition in the city hall area, garbage ship in the river, and IWMS tackle waste problems in the city. The waste issue is deemed the most critical problem. The smart environment programs haven't dealt with resources and energy issue; thus, they don't fulfil other criteria in CITYkeys' planet category.

Programs in smart society fulfil health $(\mathrm{H})$ \& safety $(\mathrm{S})$ in the people category and community engagement $(\mathrm{CE})$ in the governance category. In realizing a smart society, cutting-edge communication technology, smart economic solutions and community independence are needed to continue innovating and developing in a sustainable manner (Bazaluk 2016). SiTikTik Jumantik and flood EWS are in line with the smart society goal. They fulfil 2 out of 6 criteria in CITYkeys' people category and hasn't fulfilled other measures in a said category such as education and quality of housing \& the built environment.

In general, 10 out of 21 criteria are fulfilled in Bekasi City. The least fulfilled criteria are from the planet category. This indicates the government uses smart city programs to facilitate the necessities of the citizens and hasn't had many programs that tackle environmental problems further.

\section{CONCLUSIONS}

In general, the six pillars of smart city, i.e. smart government, smart branding, smart economy, smart living, smart environment and smart society, has been implemented in Bekasi City. It can be said that the programs' service quality varies, but most programs are good.

The government of Bekasi City needs some adjustments to improve the implementation of smart city initiatives. In terms of smart government aspects, Bekasi city needs to improve its service quality. The smart branding pillar needs to be expanded further to economic sectors regarding what direction or focus the town is going to. A smart economy needs to be developed to improve other undeveloped financial industries in the city, such as agriculture. Smart living needs to be 
expanded to other platforms such as mobile phone, especially related to citizens' awareness of energy-saving practices. A smart environment can still be developed into energy-saving by incorporating renewable energy and low-power technology. Smart society still needs to improve its service quality and education for the citizen on its programs.

Further studies on smart city in Indonesia need to be done. Indonesia has applied the smart city concept to its towns, and the programs are made according to their needs. The pillars used can be similar, but each city has different goals for achieving the standards of every post.

\section{REFERENCES}

Aletà, Neus Baucells, Concepción Moreno Alonso, and Rosa M. Arce Ruiz. (2017). "Smart Mobility and Smart Environment in the Spanish Cities." In Transportation Research Procedia 24, 163-170. https://doi.org/10.1016/j.trpro.2017.05.084.

Alifi, M. Riza, and Suhono Harso Supangkat. (2016). "Information Extraction for Traffic Congestion in Social Network: Case Study: Bekasi City." In 2016 International Conference on ICT For Smart Society (ICISS), 53-58. Surabaya. https://doi.org/10.1109/ICTSS.2016.7792848.

Angrosino, Michael V. (2004). "Nonparticipant Observation." In The SAGE Encyclopedia of Social Science Research Methods, Volume 1, 737-38. SAGE Publications.

Anttiroiko, A.V., P. Valkama, and S.J. Bailey. (2014). "Smart Cities in the New Service Economy: Building Platforms for Smart Services." AI and Society: Knowledge, Culture and Communication 29 (3): 323-34.

Bazaluk, Oleg. (2016). "The Theory of War and Peace.” 2016. http://e-notabene.ru/ fr/article 19263.html.

Bekasiekspres.com. 2019. “Kombas Ajak Masyarakat Kenali Batik Bekasi.” (2019). http://bekasiekspres.com/2019/09/22/kombas-ajak-masyarakat-kenali-batikbekasi/.

Dameri, Renata Paola. (2013). "Searching for Smart City Definition: A Comprehensive Proposal." International Journal of Computers \& Technology 11 (5): 2544-2551. https://doi.org/10.24297/ijct.v11i5.1142.

Deloitte. 2015. "Smart Cities - A Deloitte Point of View, Version 1.0." 2015. https://www2.deloitte.com/content/dam/Deloitte/tr/Documents/publicsector/deloitte-nl-ps-smart-cities-report.pdf.

Devega, Evita. (2017). "Langkah Menuju '100 Smart City." 2017. https://kominfo.go.id/content/detail/11656/langkah-menuju-100-smartcity/0/sorotan_media.

Fajri, Fitriyandi Al. (2017). "Kota Bekasi Kian Bersolek." 2017. https://wartakota.tribunnews.com/2017/02/02/kota-bekasi-kian-bersolek.

Fanny, Zayra. (2017). "Hubungan Informasi Sosialisasi Program Bekasi Smart City Dengan Sikap Peserta Terhadap Program Bekasi Smart City." Universitas Padjadjaran. 
Fioroni, Giacomo, Marco Pistore, Silvio Ranise, Giancarlo Sciascia, Michele Trainotti, Franco Amigoni, Letizia Caporusso, Francesca Gleria, and Andrea Maffeis. (2015). "Smart Government: Toward an Innovative Concept of a 'One-Stop Shop' for Interactive Online Services." In IEEE-TN SMART CITIES WHITE PAPER. https://doi.org/10.13140/RG.2.1.4882.9286.

Firdaus, Andi. (2018). "Transformasi Smart City Kota Bekasi." 2018. https://megapolitan.antaranews.com/berita/40265/transformasi-smart-citykota-bekasi.

Galperina, Liubov Pavlivna, Anna Tymofiyivna Girenko, and Valentyna Petrivna Mazurenko. (2016). "The Concept of Smart Economy as the Basis for Sustainable Development of Ukraine." International Journal of Economics and Financial Issues 6 (S8): 307-14.

Giffinger, R., C. Fertner, H. Kramar, R. Kalasek, N. Pichler-Milanovi, and E. Meijers. (2007). Smart Cities: Ranking of European Medium-Sized Cities. Vienna, Austria: Center of Regional Science (SRF):

Hall, R.E., B. Bowerman, J. Braverman, J. Taylor, H. Todosow, and U. Von Wimmersperg. (2000). The Vision of a Smart City. Upton, NY, USA: Brookhaven National Lab.

Harrison, C., B. Eckman, R. Hamilton, P. Hartswick, J. Kalagnanam, J. Paraszczak, and P. Williams. (2010). "Foundations for Smarter Cities." IBM Journal of Research and Development 54 (4): 1-16. https://doi.org/10.1147/JRD.2010.2048257.

Howard, Rick. (2013). "Smart Government Key Initiative Overview." 2013. https:/www.gartner.com/en/documents/2520516/smart-government-keyinitiative-overview.

Kurnia, Septiawan Santana. (2007). Menulis Ilmiah: Metode Penelitian Kualitatif. Jakarta: Obor Mas. . 2010. Menulis Ilmiah Metodologi Penelitian Kualitatif. 2nd ed. Jakarta: Yayasan Pustaka Obor Indonesia.

Liu, X., K. H. Lam, K. Zhu, C. Zheng, X. Li, Y. Du, Chunhua Liu, and P. W. T. Pong. (2016). "Overview of Spintronic Sensors, Internet of Things, and Smart Living.” 2016. https://arxiv.org/ftp/arxiv/papers/1611/1611.00317.pdf.

Mantalean, Vitorio. (2019). "Ini Berbagai Layanan Di Mal Pelayanan Publik Bekasi Trade Center Mall." 2019. https://megapolitan.kompas.com/read/2019/09/04/11321191/ini-berbagailayanan-di-mal-pelayanan-publik-bekasi-trade-center-mall?page=all.

_. 2020. "Pemkot Bekasi Teken MoU Smart City Dengan Waste4Change Soal Pengelolaan Sampah.” 2020. https://megapolitan.kompas.com/read/2020/03/09/19150181/pemkot-bekasiteken-mou-smart-city-dengan-waste4change-soal-pengelolaan.

McAliney, M. (1993). Arguments for Land Conservation. Documentation and Information Sources for Land Resources Protection. Sacramento, CA: Documentation and Information Sources for Land Resources Protection, Trust for Public Land.

Millard, Jeremy, Rasmus Kåre Thaarup, Jimmy Kevin Pederson, Catriona Manville, Matthias Wissner, Bas Kotterink, Gavin Cochrane, Jonathan Cave, Andrea 
Liebe, and Roel Massink. (2014). Mapping Smart Cities in the EU. Industry, Research and Energy, European Parliament. https://doi.org/10.2861/3408.

Mohanty, Saraju P. (2016). "Everything You Wanted to Know About Smart Cities." IEEE Consumer Electronics Magazine $5 \quad$ (3): 60-70. 10.1109/MCE.2016.2556879.

Northstream. (2010). White Paper on Revenue Opportunities. Stockholm, Sweden: Northstream.

Pasquinelli, Cecilia. (2015). "City Branding and Local SMEs: A Smart Specialisation Perspective." Symphony Emerging Issues in Management, no. 1: 63-76.

Patabuga, Reynold, Eko Priyo Purnomo, and Aulia Nur Kasiwi. (2019). "Pengembangan Smart Branding Sebagai Langkah Awal Menuju Terwujudnya Smart City Di Kota Tomohon.” Jurnal Ekonomi Pembangunan 5 (2): 116-26.

Pemerintah Kota Bekasi. (2020). "Tinjau Lapangan Implementasi Manfaat Program Smart City Kota Bekasi." 2020. https://www.bekasikota.go.id/detail/tinjaulapangan-implementasi-manfaat-program-smart-city-kota-bekasi.

Rachmat. (2018). "Rapat Penetapan RT RW Untuk Implementasi Kawasan Smartcity Kota Bekasi." 2018. https://diskominfo.bekasikota.go.id/home/detail/186/Rapat-Penetapan-RTRW-Untuk-Implementasi-Kawasan-Smartcity-Kota-Bekasi.

Sanjaya, I Made Ariya, Suhono Harso Supangkat, and Jaka Sembiring. (2018). "Citizen Reporting Through Mobile Crowdsensing: A Smart City Case of Bekasi." In 2018 International Conference on ICT for Smart Society (ICISS), 1-4. Semarang. https://doi.org/10.1109/ICTSS.2018.8549976.

Saputra, Rizqiya Windy, Suhono H. Supangkat, and Rofiq Iqbal. (2017). "Waste Utilities Development in Industrial Zone Based on Smart City Concept and Co-Creation: Case Study in Bekasi City." In 2017 International Conference on ICT For Smart Society (ICISS), 1-5. Tangerang. https://doi.org/10.1109/ICTSS.2017.8288867.

Shamsi, Rashed Shtait Hamad AL, Ali Abdulbaqi Ameen, Osama Isaac, Ahmed Hamoud Al-Shibami, and Gamal Sayed Khalifa. (2018). "The Impact of Innovation and Smart Government on Happiness: Proposing Conceptual Framework." International Journal of Management and Human Science (IJMHS) 2 (2): 10-26.

Valentyna, Voronkova, Kyvliuk Olga, Nikitenko Vitalina, and Oleksenko Roman. (2018). "Stem-Education" as a Factor in the Development of" Smart-Society": Forming of" Stem-Competence." 2018. https://dspace.znu.edu.ua/jspui/bitstream/12345/720/1/gvzdia_72_12.pdf.

Widodo, Aan, and Diah Ayu Permatasari. (2020). "Strategi Komunikasi Pemerintah Kota Bekasi Dalam Program Bekasi Smart City." ETTISAL 5 (1): 79-89. https://doi.org/http://dx.doi.org/10.21111/ejoc.v5i1.3454.

Zanella, Andrea, Nicola Bui, Angelo Castellani, Lorenzo Vangelista, and Michele Zorzi. (2014). "Internet of Things for Smart Cities." IEEE Internet Things Journal 1 (1): 22-32. https://doi.org/10.1109/JIOT.2014.2306328. 
Michelle, Felasari: SMART CITY IMPLEMENTATION IN BEKASI CITY

This Page is Intentionally Left Blank 